\title{
Pencegahan Penularan COVID-19 Melalui Penguatan Perilaku Siswa dan Guru SDK Seoam 1 Eban Kecamatan Miomaffo Barat
}

\author{
Grandianus Seda Mada'), Dicky Frengky Hanas ${ }^{2)}$,Lukas Pardosi ${ }^{2)}$, \\ Welsiliana $^{2)}$, Didi Prasetyo Benu' ${ }^{3)}$, Marselina Theresia Djue Tea ${ }^{3)}$, \\ Dira Asri Pramita ${ }^{4}$, Desta Gloria Siahaan ${ }^{5)}$ \\ 1)Program Studi Matematika, Fakultas Pertanian, Universitas Timor, Indonesia \\ ${ }^{2)}$ Program Studi Biologi, Fakultas Pertanian, Universitas Timor, Indonesia \\ ${ }^{3)}$ Program Studi Kimia, Fakultas Pertanian, Universitas Timor, Indonesia \\ 4)Program Studi Agribisnis, Fakultas Pertanian, Universitas Timor, Indonesia \\ ${ }^{5}$ Program Studi Pendidikan Bahasa Inggris, Fakultas Ilmu Pendidikan, Universitas Timor, \\ Indonesia \\ Email: grandianusmada@gmail.com
}

\begin{tabular}{|l|l|l}
\hline Dikirim: 22-01-2021 & Direvisi: 19-03-2021 & Diterbitkan: 31-08-2021
\end{tabular}

\begin{abstract}
Abstrak
Salah satu alasan sekolah masih belum dibuka secara penuh hingga kini adalah potensi terjadinya penularan melalui siswa-siswa yang berkumpul dalam waktu lama di ruang tertutup. Beberapa penelitian menunjukkan bahwa menutup sekolah akan memperlambat perkembangan infeksi. Namun, langkah-langkah yang lebih luas seperti social distancing, terbukti memiliki efek pengendalian yang lebih besar. Resiko dari pembukaan sekolah akan bergantung pada seberapa baik sekolah mengendalikan penularan, misalnya dengan penggunaan masker dan membatasi okupansi. Oleh karena itu, perlu dilakukan kembali penguatan perilaku untuk mencegah penularan penyakit Covid-19 kepada siswa dan guru. Bentuk Kegiatan Pengabdian yang dilakukan adalah pembagian masker dan edukasi mengenai dampak penyakit Covid-19 kepada siswa dan guru SDK Seoam 1 Eban, Kefamenanu. Hasil dari kegiatan ini adalah para siswa dan guru dapat melakukan protokol kesehatan secara sadar dan benar yaitu melalui 3M: memakai masker, menjaga jarak dan menghindari kerumunan, serta mencuci tangan pakai sabun.
\end{abstract}

\section{Kata Kunci: Covid-19, Protokol Kesehatan, Guru dan Siswa}

\begin{abstract}
One of the reasons that schools have not been fully opened up untilnow is the potential for transmission through students who have got together for a long time in a closed room. Several studies have shown that closing schools will slow the progression of infection. However, broader ways such as social distancing has been shown to have a greater controlling effect. The risk of opening schools will depend on how well schools control transmission, for example by wearing a mask and limiting occupancy. Therefore, it is necessary to reinforce behavior again to prevent transmission of the Covid19 disease to students and teachers. The form of Community Service activities carried out was the distribution of masks and education about the impact of the Covid-19 disease to students and teachers of Catholic Elementary School Seoam 1 Eban, Miomaffo Barat. The result of this activity showed that students and teachers can carry out health protocols consciously and correctly through wearing masks, keeping distance and avoiding crowds, and washing hands with soap.
\end{abstract}




\section{Keywords: Covid-19, Health Protocol, Teachers and Students}

\section{PENDAHULUAN}

Korban jiwa karena pandemi Covid-19 terus berjatuhan. Di banyak negara, virus ini sebagian besar memakan korban dari kalangan lanjut usia. Anak-anak yang terkena virus, cenderung lebih dapat bertahan tapi kondisinya sangat menular sehingga juga harus diisolasi. Sementara di Indonesia, dikutip dari data yang dirangkum oleh Pandemic Talks, platform info dan data Covid-19 Indonesia dari spektrum sains dan ekosospol, mengungkap kalau kasus Covid-19 pada anak di Indonesia tembus 15.677 kasus. Jumlah tersebut terbilang sangat tinggi dan mengkhawatirkan dan terdapat beberapa fakta mengejutkan yaitu jumlah kasus anak yang terkena Covid-19 di Indonesia lebih besar dari gabungan total kasus di negara Malaysia (9.559 kasus) dan Thailand (3.447 kasus). Jika anak-anak Indonesia memiliki sebuah negara sendiri, maka negara tersebut berada di posisi 82 Klasemen Global Total Kasus Covid-19 Negara. Untuk bayi usia 0-1 tahun yang terinfeksi Covid-19, sebanyak 1.851 bayi. Angka itu setara 1,7\% total kematian akibat Covid-19, yang menurut Ikatan Dokter Anak Indonesia, salah satu yang tertinggi di Asia dan dunia. Hal ini juga sejalan dengan penelitian (Flasche and Edmunds, 2020) tentang peran sekolah dan anak usia sekolah dalam penyebaran Covid-19.

Walaupun pandemi virus corona masih berlangsung, berbagai negara di dunia termasuk Indonesia mulai menyusun dan menerapkan kebijakan-kebijakan tertentu agar aktivitas warga negaranya dapat berjalan kembali, salah satu yang menjadi sorotan adalah soal pembukaan sekolah. Li et al. (2020) menyatakan bahwa sekolah memiliki peran yang penting dalam menentukan kesejahteraan anak-anak, karena sekolah bukan hanya tempat untuk belajar, tapi juga untuk bersosialisasi dan berolahraga. Bagi beberapa anak sekolah juga menjadi tempat untuk merasa aman. Beberapa sekolah telah mempraktikkan sistem online learning, namun sistem ini tidaklah universal, karena tidak semua anak dapat mengaksesnya. Bagi anak-anak yang kurang beruntung, mereka akan tertinggal dan semakin kehilangan pendidikan penting karena adanya penutupan sekolah-sekolah.

Munro and Faust (2020) menyatakan bahwa bahwa proses pembukaan kembali sekolah dapat mulai dilakukan secara bertahap, asalkan tetap diikuti oleh berbagai langkah pencegahan penyebaran virus corona. Yakob et al. (2020) menyatakan bahwa, salah satu cara pencegahan penyebaran Covid-19 adalah disiplin mencuci tangan dengan sabun. Cara ini juga harus dikenalkan dan mulai diajarkan kepada anak-anak. Virus corona dapat menular melalui droplet atau percikan air liur. Percikan itu berpotensi keluar dari mulut penderita saat bersin atau batuk. Jika percikan tersebut menempel ke tangan atau permukaan benda-benda yang sering disentuh, maka virus akan dengan mudah masuk ke tubuh. Kabar baiknya, virus ini dapat mati jika mencuci tangan dengan air mengalir dan sabun, atau menggunakan hand sanitizer yang mengandung alkohol dengan kadar setidaknya 70\%. Jadi, apabila ada droplet yang mengandung virus corona menempel di tangan, virus ini dapat hilang dengan cuci tangan sehingga tidak tertular.

Anak-anak perlu mendapatkan informasi yang memadai dan mudah dipahami agar dapat turut serta melaksanakan beragam upaya pencegahan Covid-19 yang telah dicanangkan oleh pemerintah. Salah satu media yang disukai anak adalah media bergambar. Media tersebut mudah dipahami dan lebih diminati di kalangan anak usia sekolah dasar. Sebuah gambar dapat 
menginspirasi dan memicu pemikiran siswa untuk berangan-angan dan memahami materi (Masruro, 2018 dalam Sari,2020).

SDK Seoam 1 Eban beralamat di Desa Eban, Kecamatan Miomaffo Barat. Desa ini berjarak $35 \mathrm{Km}$ dari pusat Kota Kefamenanu, memiliki kontur wilayah berbukit serta memiliki penduduk yang sebagian besarnya adalah petani. Tentunya jika sistem online learning tetap dijalankan maka tidak semua siswa dapat mengikuti dengan optimal dikarenakan alasan ekonomi dan tingkat kualitas jaringan internet. Oleh karenanya SD ini telah kembali beroperasi dengan mengikuti berbagai protokol kesehatan seperti pemberlakuan shift kelas, waktu belajar dalam ruangan yang dikurangi dan lain sebagainya. SDK Seoam 1 Eban juga memiliki jarak yang sangat dekat Pasar Eban yang merupakan pusat perekonomian Desa Eban. Hal ini tentunya memperbesar penyebaran Covid-19 karena aktivitas masyarakat yang padat pada hari pasar Eban berlangsung.

Berdasarkan pertimbangan di atas, kemudian diadakan kegiatan pengabdian pada masyarakat seperti pembagian masker, pembagian dan penempelan stiker penjelasan mengenai protokol kesehatan untuk mencegah penularan Covid-19, serta penjelasan cara mencuci tangan yang baik dan benar bagi guru-guru dan siswa-sisa SDK Seoam 1 Eban.

\section{METODE}

Pengabdian dilaksanakan pada SDK Seoam 1 Eban, Kecamatan Miomaffo Barat dengan sasaran pengabdiannya adalah para guru dan siswa. Terdapat tiga tahapan pengabdian yaitu survei awal, koordinasi panitia pengabdian dan pelaksanaan pengabdian. Pengabdian dilakukan dengan metode ceramah mengenai apa itu Covid-19, bagaimana cara penyebarannya dan apa saja upaya yang dapat dilakukan dalam mencegah penyebaran virus tersebut. Selain memberikan ceramah, dilakukan pula pembagian masker dan stiker yang berisi penjelasan mengenai pencegahan penyebaran Covid-19 serta mencontohkan cara mencuci tangan dengan sabun yang baik dan benar kepada para siswa.

\section{HASIL DAN PEMBAHASAN}

Kegiatan pengabdian kepada masyarakat tentang pencegahan penularan Covid-19 melalui penguatan perilaku siswa dan guru SDK Seoam 1 Eban Kecamatan Miomaffo Barat dilaksanakan pada Selasa, 15 Desember 2020. Sebelum pengabdian berlangsung, dilakukan survei ke sekolah untuk keperluan permohonan ijin pengabdian dan pengecekan jumlah mahasiswa. Proses survei dapat dilihat pada Gambar 1. 


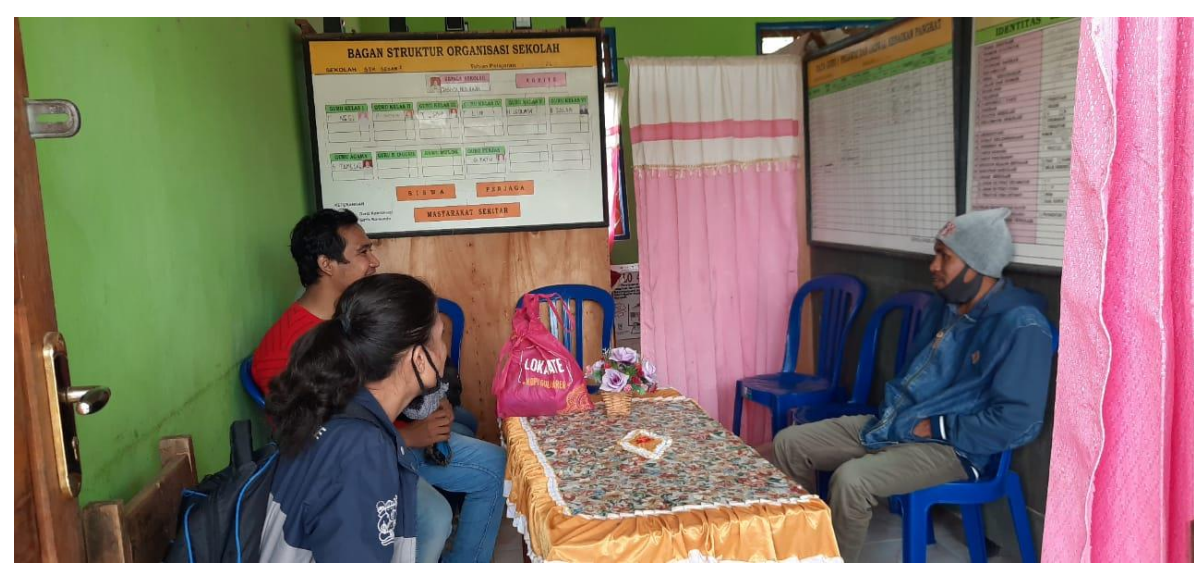

Gambar 1: Survei Lokasi Pengabdian

Kegiatan Pengabdian kepada Masyarakat dilakukan dalam bentuk pembagian masker dan stiker, serta edukasi mengenai dampak penyakit Covid-19 dan upaya pencegahan penyebaran virus Covid-19. Stiker yang dibuat berisikan tata cara pencegahan penyebaran virus Covid-19 yang dianjurkan pemerintah (Gambar 2). Stiker ada yang ditempel di depan kelas, depan gerbang sekolah dan ada yang dibagikan kepada siswa-siswa untuk ditempel di rumah masing-masing (Gambar 3).

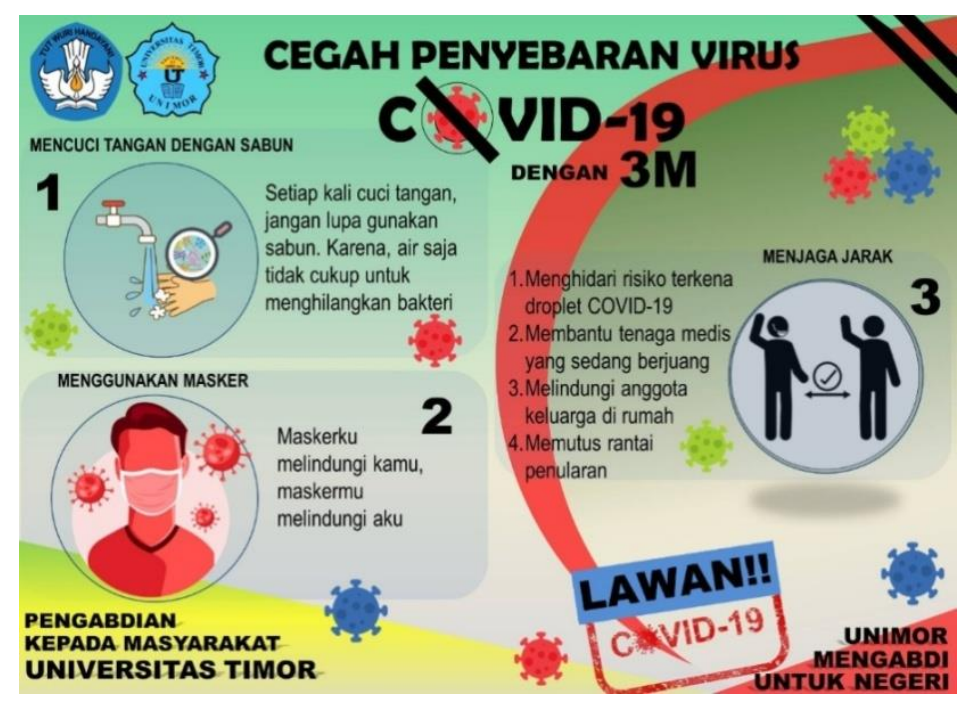

Gambar 2. Stiker yang dibagikan di SDK Seoam 1 Eban

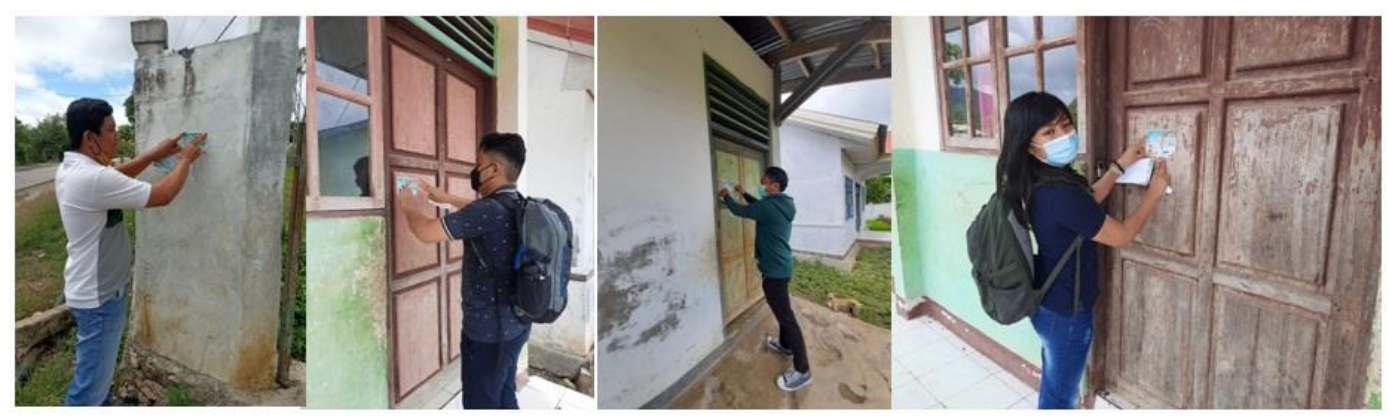

Gambar 3. Penempelan stiker di lingkungan SDK Seoam 1 Eban 
Edukasi mengenai dampak penularan dan upaya pencegahan terpaparnya tubuh oleh virus Corona dilakukan bersamaan dengan pembagian masker dan stiker. Edukasi dilakukan dengan baik dan bagian yang paling ditekankan adalah upaya pencegahan penularan virus Corona dengan melakukan 3M, yaitu yaitu memakai masker, menjaga jarak dan menghindari kerumunan, serta mencuci tangan pakai sabun. Proses pembagian masker kepada para siswa dapat dilihat pada Gambar 4.

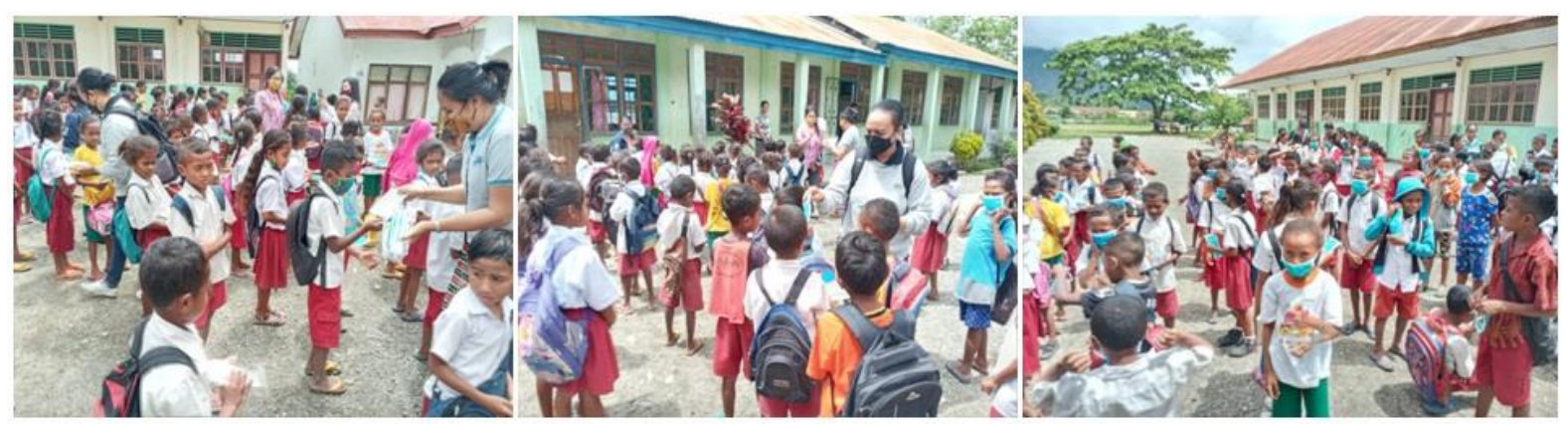

Gambar 4. Pembagian Masker ke Guru dan Siswa SDK Seoam 1 Eban

Kepada para siswa diajarkan cara mencuci tangan dengan sabun yang baik dan benar melalui media lagu sehingga para siswa dapat mempraktekkannya sambil bernyanyi dan pada akhirnya akan mudah diingat. Juliawan et al. (2019), Yuhanna and Mumtahanah (2019) dan Faijah (2019) menyatakan bahwa mengajari anak-anak cara mencuci tangan dengan sabun yang baik dan benar melalui lagu dapat menarik minat dan meningkatkan daya ingat anak-anak untuk terus membiasakan diri mereka mencuci tangan dengan sabun. Cara-cara mencuci tangan yang baik dan benar dapat dibaca pada Susantiningsih et al. (2018). Proses pengajaran cara mencuci tangan yang baik dan benar kepada para siswa dapat dilihat pada Gambar 5.

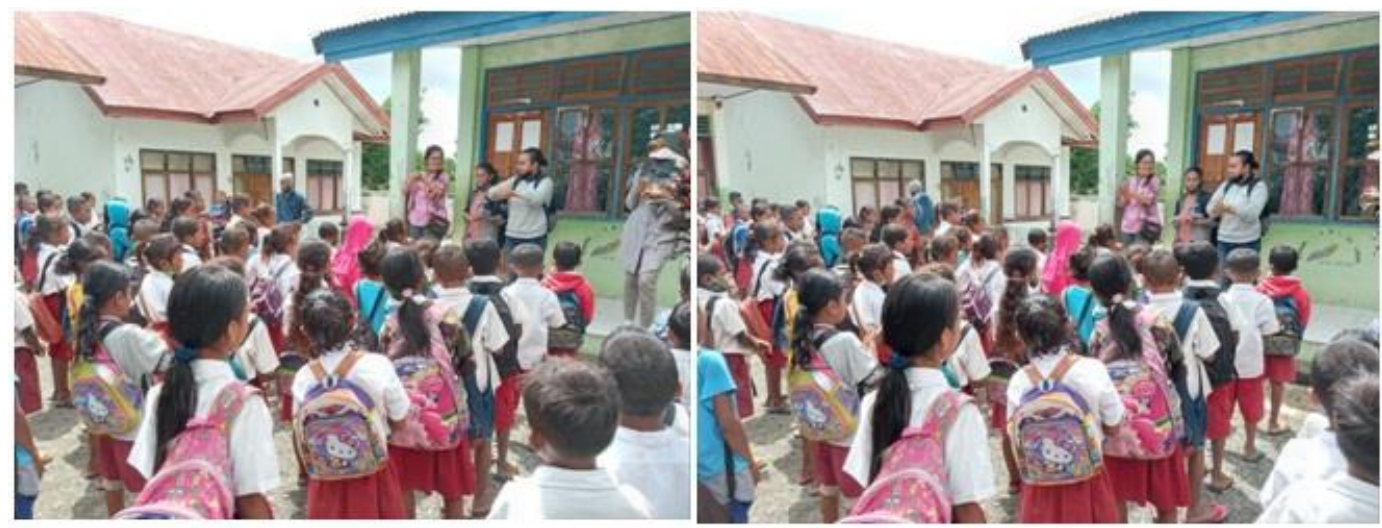

Gambar 4. Edukasi Cara Mencuci Tangan dengan Sabun yang Baik dan Benar

Secara keseluruhan para guru dan siswa SDK Seoam 1 Eban memberikan respon yang baik dan sangat antusias terhadap kegiatan ini. Selama kegiatan berlangsung didapati bahwa tidak semua guru dan siswa SDK Seoam 1 Eban menggunakan masker, terbatasnya informasi berupa stiker yang ditempelkan pada lingkungan sekolah, serta kurangnya informasi terkait dampak dan upaya pencegahan Covid-19, sehingga kegiatan ini dinilai oleh para guru sangat bermanfaat. Diharapkan agar respon dan rasa antusias ini terus mendorong para guru dan siswa 
agar secara sadar dan benar dapat melakukan protokol kesehatan (3M) untuk mencegah penyebaran virus Corona sehingga jumlah pasien penderita Covid-19 tidak bertambah.

\section{SIMPULAN}

Dampak langsung yang diperoleh dari pelaksaan kegiatan pengabdian ini adalah:

a. Guru dan siswa SDK Seoam 1 Eban mendapatkan masker dan stiker. Stiker juga ditempelkan pada lingkungan sekolah.

b. Guru dan siswa SDK Seoam 1 Eban mendapatkan informasi tentang dampak dan upaya pencegahan penyebaran Covid-19.

c. Siswa SDK Seoam 1 Eban mengetahui cara mencuci tangan dengan sabun yang baik dan benar.

\section{UCAPAN TERIMA KASIH}

Ucapan terimakasih untuk LPPM Universitas Timor yang telah mendukung kegiatan pengabdian ini serta pihak guru-guru SDK Seoam 1 Eban yang telah mengijinkan kami melakukan kegiatan pengabdian.

\section{DAFTAR PUSTAKA}

Faijah, F dan Nurlaila. 2019. Penerapan Metode Bernyanyi untuk Meningkatkan Kemampuan Cuci Tangan pada Anak di TK Mekarsari Ambalresmi. The $10^{\text {th }}$ University Research Colloqium 2019 pp 8-13.

Flasche, S and W. John Edmunds. 2021. The Role of Schools and School-Aged Children in SARS-CoV-2 Transmission. The Lancet Infectious Diseases, Dec. 2020, p. S1473309920309270. DOI.org (Crossref), doi:10.1016/S1473-3099(20)30927-0.

Juliawan, D.G., N.K.A. Mirayanti dan N.A. Parwati. 2019. Pengaruh Pendidikan Kesehatan Dengan Bernyanyi Lagu Cuci Tangan Terhadap Tindakan Mencuci Tangan Anak Prasekolah. Journal Center of Research Publication in Midwifery and Nursing, 3(1):1120. doi:10.36474/caring.v3i1.124.

Li, W., J. Lu., S. Liu., Z. Chang., C. Peng., X. Liu., P. Zhang., Y. Ling., K. Tao and J. Chen. 2020. Characteristics of Household Transmission of COVID-19." Clinical Infectious Diseases, 71(8) :1943-1946. doi:10.1093/cid/ciaa450.

Munro, A.P.S and S. N. Faust. 2020. Children Are Not COVID-19 Super Spreaders: Time to Go Back to School. Archives of Disease in Childhood, 105 (7): 618-19. doi:10.1136/archdischild-2020-319474.

Sari, M.K. 2020. Sosialisasi Tentang Pencegahan Covid-19 Di Kalangan Siswa Sekolah Dasar Di SD Minggiran 2 Kecamatan Papar Kabupaten Kediri. Jurnal Karya Abdi, 4(1) : 8183. doi:https://doi.org/10.22437/jkam.v4i1.9821.

Susantiningsih, T., R. Yuliyanti., K. Simanjuntak dan Arfiyanti. 2018. PKM Pelatihan Mencuci Tangan Menggunakan Sabun Sebagai Perilaku Hidup Bersih dan Sehat Untuk Masyarakat RT 007/RW 007 Desa Pangkalan Jati, Kecamatan Cinere Kota Depok. Jurnal Bakti Masyarakat Indonesia, 1(2) : 75-84. doi:10.24912/jbmi.v1i2.2889.

Yakob, M., M.T. Hidayat., A. Suciani dan P. Nucifera. 2020. Strategi Pencegahan Penularan Virus COVID-19 Pada Sekolah Dasar Di Kecamatan Pante Bidari Aceh Timur. 
International Journal of Community Service Learning, 4 (3) : 209-214. doi:10.23887/ijcsl.v4i3.29095.

Yuhanna, W.L dan M. Mumtahanah. 2019. Upaya Meningkatkan Kebiasaan Mencuci Tangan melalui Hand Washing Dance pada Siswa PAUD Al Abror Desa Bulakrejo Kabupaten Madiun. BAKTIMAS: Jurnal Pengabdian pada Masyarakat, 1(1) : 13-19. doi:10.32672/btm.v1i1.1178. 